 \\ $D$ \\ Engineering Heritage Journal /Galeri Warisan Kejuruteraan \\ Journal Homepage: http://www.razipublishing.com/journals/galeri-warisan-kejuruteraan-gwk/ https://doi.org/10.26480/gwk.01.2017.01.05
}

\section{Comparison Method Of Odour Impact Evaluation Using Calpuff Dispersion Modelling And On-Site Odour Monitoring}

\author{
Nurashikin Yaacof, Nastaein Qamaruzzaman, Yusri Yusup
}

1,2School of Civil Engineering, Universiti Sains Malaysia, 14300 Nibong Tebal, Pulau Pinang, Malaysia

${ }^{2}$ Solid Waste Management Cluster, Engineering Campus, Universiti Sains Malaysia

${ }^{3}$ Environmental Technology, School of Industrial Technology, Universiti Sains Malaysia, 11800Pulau Pinang, Malaysia

ashikinyaacof88@gmail.com, ${ }^{b}$ cenastaein@usm.my, cyusriyp@gmail.com

This is an open access article distributed under the Creative Commons Attribution License, which permits unrestricted use, distribution, and reproduction in any medium, provided the original work is properly cited

ART I C LE DETAILS

\section{Article history:}

Received 12 September 2016

Accepted 20 December 2016

Available online 10 January 2017

\section{Keywords:}

Odour concentration, palm

oil mill, olfactometry, calpuff,

dispersion modeling
A B S T R A C T

Until now, the suitable types of odour assessment technology in Malaysia still cannot be found and at the same time, there is no odour regulation concerning the specific odour parameter stated in the Environmental Quality Act 1974. The assessment of odour pollution is still regarded as a difficult task but the development of odour pollution assessment and proper regulatory tools are urgently needed. This paper aim to compare two methods for determining odour concentration which are field inspection and atmospheric dispersion model (CALPUFF). This research goal was to compare both method estimation of odour in quantitatively and qualitatively. The comparison will highlight the strength and weakness of both methods. CALPUFF is an easy method in knowing the whole picture of the dispersion but it is still new in Malaysia, while field inspection takes into account the role of human perception but it need a lot of work to obtain the whole picture of the dispersion. Palm oil mill was chosen as the study site since palm oil mill effluent (POME) release high contribution in emitted unpleasant odour [1]. 18 possible receptors points were chosen which include residential area, institution and also public area. It was found that, both methods show that the odour concentration is higher at the receptor near the source but different in odour concentration values. Both methods have their own advantage and disadvantages and it can be conclude that, both of it provide reasonable estimation of odour nuisance but it also depends on the odour case situation such as the availability of data and the number of odour source where sometimes one of the method is the proper method to be use at that time.

\section{Introduction}

Odorous gases are particular kind of air pollutants. It is one of the major environmental problems that several industrial categories have to face. Odour pollution is widely recognised as the offensive air pollution due to human activity usually in populated areas. In the last 30 years, odour nuisances from different industrial sources have become a serious environmental concern [2]. By definition, odour is the aggregate of a mixture of gases on the sense of smell. Its strength is determined by using odour detection threshold (ODT). The ODT is the number of dilutions with odour free air required for an odour to be just detected by $50 \%$ of the odour panel or until the least definitely perceptible odour is achieved [3].

Offensive odours came in various kinds of sources such as fish mills, sewage treatment, petrochemical and solvent plants are common sources of odorous emissions[4]. The unpleasant smell that came from those facilities may create a poor perception from local community towards the facility, will reduce the worker efficiency and can lead to various kinds of disease. Odours that result directly or indirectly from human activities and that cause an adverse effect are often classified as contaminants and are subject to regulation[5] and to do so, proper monitoring and regulatory tools are required to minimize the impacts of odorous emissions on human populations [6].

Usually, odour concentration was expresses in $\mathrm{OU} / \mathrm{m}^{3}$, and particularly, $10 \mathrm{U} / \mathrm{m}^{3}$ means the $10 \mathrm{U}$ of odour in $1 \mathrm{~m}^{3}$ of volume.0U $/ \mathrm{m}^{3}$ represent the number of dilutions with air that needed to the odour can be detected at its detection threshold [4]. Threshold is a concentration of odour that can be detected by human nose. Olfactometer is the equipment used in measuring odour concentration and it used human odour detection threshold in knowing the value of the amount of odorants present in $1 \mathrm{~m}^{3}$ of odorous gas under the standard condition [7]. Mostly the odour can be detected at 2 to $5 \mathrm{OU} / \mathrm{m}^{3}[8]$.

According to Ranzato et al., assessing the odour pollution is a complex task because of first, it is hard to detect the odourants since there are a lot of numbers of odorant in the ambient air. Second, time and meteorological conditions usually the factors that change the odour intensity and third, odour perception is largely subjective [6]. Because of these reasons, it is hard to identify the right and suitable method in assessing the odour concentration and set the regulation. Despite that, there are already fundamental method in sampling method and measuring the odour concentration at the source and in Malaysia MS 1963:2007 is the standard referred when running the odour sampling. Before assess the odour nuisance at the receptor, it is important in knowing the odour concentration released at the source.

Nowadays, there are various methods have been developed in assessing the odour concentration. The right method need to be chosen according to the suitability of the odour assessment situation since the odour assessment depends on the measurements and usually are based on human sensitivity. According to Capelli et al., the odour characterization techniques can be categories into three types which are analytical method, sensorial method and senso-instrumental method [4]. Analytical techniques are the method where the sample will be separate, identified and quantified by using specific instrument. Method that usually being used is gas chromatography-mass spectrometry (GCMS). This method will give the concentration of the substance rather than give the odour concentration unit and it is suitable in measuring the substance that become surrogate to the odour such as hydrogen sulphide, $\mathrm{H}_{2} \mathrm{~S}$ and ammonia, $\mathrm{NH}_{3}$. The results are different if sensorial and senso-instrumental method is use. Sensorial method is the method that uses the human nose as a sensor to characterize the odour by using the panel's sensitivity on the odour sample. Olfactometer is the equipment that usually being used in running the odour analysis and the results will be in odour concentration unit [9]. Last but not least is the sensoinstrumental method. This third method is the method that used artificial noses that perform similar just like the function of the human olfaction system [10]. Those techniques are the method that usually used in odour sampling and all the methods have its own ways or calculation in measuring the odour concentration and estimating the odour emission rate.

However, the GCMS does not offer any practical information about the perception of the odorants, which is subjective and not generally related to their concentrations in a clear way [11]. For this reason, odors are commonly measured with a second method and third method but sensorial method is preferable at the source measurement since that method can give the emission value instead of concentration only and the absent of a variable odor background that may strongly 
affect the panel response (EN 13725, 2003). Senso-instrumental or field inspection method is perfect in measuring odour at the receptors. Not only that, odour at the receptors can also be determined by using mathematical dispersion model.

CALPUFF is the modeling software used in this study. CALPUFF is one of the long rang transport (LRT) dispersion modeling and it is an advanced non steady state meteorological and air quality modeling system that using the Gaussian puff model as the basic [12]. CALPUFF is being developed by Earth Tech, Inc. [15] and been recommended by the US Environmental Protection Agency (EPA) as a guideline model for LRT and on a case by case basis for near field application in 2003 [13]CALPUFF was usually being selected because it could be run easily for single sources under multiple parameters to evaluate model sensitivity [12].

The field inspection in this study is based on a number of visits at the receptors by trained odour assessors to record and identify the perceived odours. In field olfactometer was used to analyse the odour emission at the possible receptors.The goal of this work is to compare the odour impact assessed by these two new methods in Malaysia, the odour frequency by using each method and to discuss strengths and weaknesses of the two techniques emerging from the comparison. To carry out a full comparison, the odor impact predicted by the model was compared to the field inspection both qualitatively and quantitatively.

\section{Material and Method}

\subsection{Case Study Description and Identification of the Odour Source}

A palm oil mill that located in Nibong Tebal, Pulau Pinang was chosen as the study site in this research. The study was focused on the POME treatment pond. Since the treatment pond used anaerobic process, that area is the highest area in releasing the odour gases such as $\mathrm{NH}_{3}$ and $\mathrm{H}_{2} \mathrm{~S}$ [14]. Fig. 1 shows the location of the mill at the coordinate of $5^{\circ}$ $9^{\prime} 13.63^{\prime \prime} \mathrm{N}$ and $100^{\circ} 30^{\prime} 27.90$ "E. The maximum capacity of the mill is 720 metric tons/day and the average quantity of fruit to be processed is 540 metric tons/day. This POME treatment uses anaerobic digestion pond as their wastewater treatment method. CALPUFF dispersion modeling and field inspection are the method used to quantify the odor impact due to the operation of the mill. These methods were compared by run the process to the same area for three alternate days in assessing the dispersion of odour from the mill.

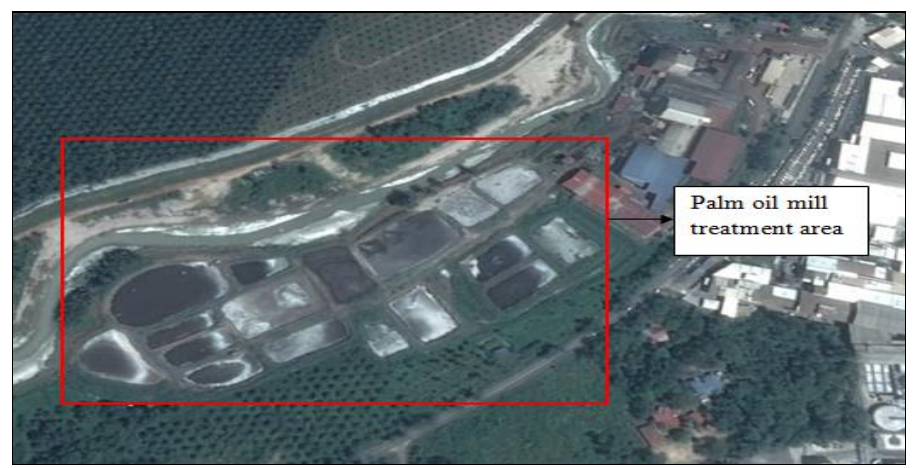

Fig. 1 Palm oil mill at Nibong Tebal and its location of the effluent treatment area (Google Earth)

The first step for assessing the odor impact was to identify the odour concentration at the sources. There are four different treatment ponds were chosen to do the odour sampling, those are acid pond, anaerobic pond, facultative pond and also aeration pond. The odour sampling was doneduring morning ( 9 a.m. to 12 p.m.) and evening ( 3 p.m. to 6 p.m.) in three alternate days and the average was taken from it to get only one odour concentration value. Odour sampling was done by using flux hood method with vacuum chamber as the media to collect the gases. Then, the gas sample was keep in the nalophan bag and brought to the laboratory to be analyse by using olfactometer within 24 hours. Odour measurement by using olfactometer and the sampling method was based on the dynamic olfactometry procedure MS 1963:2007.

$$
E=C \frac{f}{A}
$$

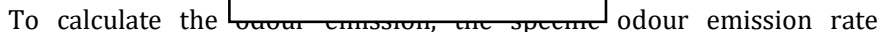

equation was used. It is important as the input to the air dispersion modeling:

Where $\mathrm{E}$ is the specific odour emission rate $\left(\mathrm{OU}_{\mathrm{E}} / \mathrm{sm}^{2}\right), C$ is the concentration of odour $\left(\mathrm{OU}_{\mathrm{E}} / \mathrm{m}^{3}\right)$ that derive from olfactometry assessment, $f$ is the volume of carrier gas per unit time $\left(\mathrm{m}^{3} / \mathrm{s}\right)$ which is $1.167 \mathrm{E}^{-4} \mathrm{~m}^{3} / \mathrm{s}$ and $A$ is the cross sectional area of flux chamber $\left(\mathrm{m}^{2}\right)$ $0.155 \mathrm{~m}^{2}$. According to Hudson et al., this equation is assumed that there is no background odour from the sweep air and there is complete mixing between the air flow and odorous air [15].

\subsection{Field Inspection}

The field inspection procedure was carried out by using portable olfactometer, SM100, by five qualified odour assessors that selected by using dynamic olfactometry procedure (MS 1963:2007, EN 13725:2003). The same panel that past in n-butanol odour sensitivity was used in identified the odour at the receptors and odour at the source. Since palm oil mill had its own special smell that can be characterize, the odour panels was trained to recognize its odour at the source and then taken to the outdoor to recognize the odour from the mill at the receptors. They need to remember the smell from the mill and had to be successful in recognizing the smell to be appointed as the odour panel in this study. All the odour characters need to be recorded during the monitoring including the background odour such as grass and dirt.

There are 18 receptors that already being identified affected by the offensive smell from the mill. Those receptors were identified by running the survey at the residential areas around the source. Fig. 2 shows the image of the 18 external point's location around $4 \mathrm{~km}$ from the mill. For the field inspection was run in three session, morning ( 9 a.m to 12 p.m), evening ( 3 p.m to 6 p.m) and night time (12 a.m to 3 a.m). The data was taken in different hour at each receptors point to take different meteorological condition into account.

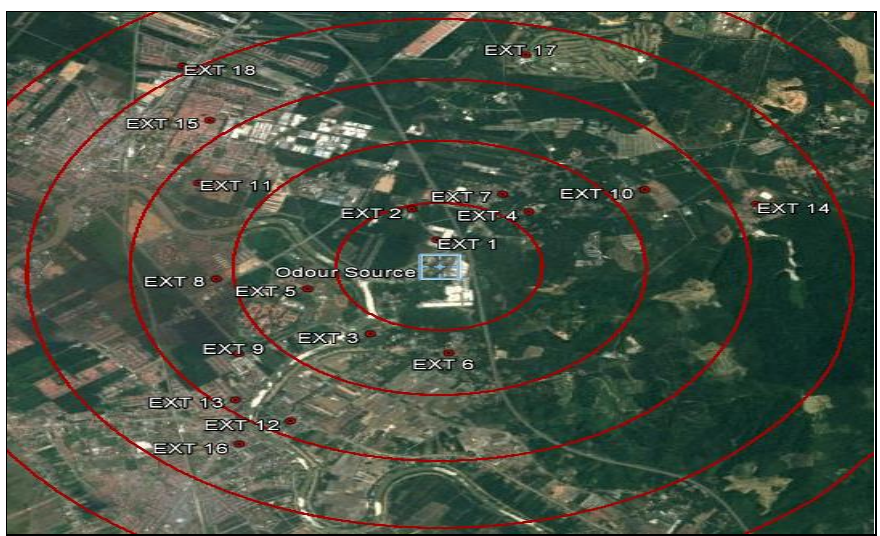

Fig. 2 External points map layout by $1 \mathrm{~km}$ at each radius circle (Google Earth)

In-field olfactometer was used in measuring the ambient odour concentration especially at the receptors. It is easy way in obtain the odour concentration immediately without combine with the other equipments and without being analyse in the laboratory. In-field olfactometers are portable devices with a source of clean filtered air and a dilution system based on several calibrated orifices. Scentroid SM100 field olfactometer was used in this research. The SM100 olfactometer (Scentroid, Canada) draws a sample of ambient air via venture pump and dilutes it using fresh odourless air from a compressed air tank.

Unlike other infield odour measuring devices (e.g. Nasal Ranger, St. Croix Sensory) SM100 does not rely on filters to clean ambient air for dilution. Rather, fresh odourless air is supplied by a portable light weight high pressure air tank. During the measurement, as in the laboratory dynamic olfactometry, user increase the value of detection threshold $(\mathrm{D} / \mathrm{T})$ until an individual threshold of the odour is achieved. The measurement principle was according to international standard, ASTM E679-04 (2011) and EN 13725 (2003).

\subsection{Atmospheric Dispersion Modeling}

In this study, CALPUFF dispersion model was used to estimate odor emissions and predict odor concentrations from industrial complex area sources.Regulatory models such as CALPUFF are commonly employed to simulate the atmospheric dispersion of odorant compounds. There are three main components in CALPUFF which are CALMET, 
CALPUFF, and CALPOST. CALMET is a meteorological model that develops hourly wind and temperature fields on a 3D gridded modeling domain. CALPUFF is a transport and dispersion model that describes "puff" of material emitted from modeled sources, simulating dispersion and transformation processes along the way. CALPOST is used to process the files from CALPUFF, processing a summary of the simulation results in tabulated forms. CALPUFF was chosen to be use in this study because the final results it give is more accurate compare to the other dispersion modeling such as AERMOD and AUSPLUME [16].

In this research, CALPUFF was configures for an analysis of terrain and land use data is at $50 \mathrm{~km}$ by $50 \mathrm{~km}$ study domain with the centered point is at the palm oil mill. The study was run for 24 hours at each three sampling days. Meteorological input prepared for CALPUFF is by using MM5 data with domain size $100 \mathrm{~km}$ by $100 \mathrm{~km}$ and $4 \mathrm{~km}$ resolution from the Lakes Environmental Software. Predictions of odour concentrations were generated from the contributions of odour from the four main treatment ponds. The model was run in no-obs mode since the MM5 data was fully used without backup meteorological data. The number of grid spacing is $200 \mathrm{~km}$ by $200 \mathrm{~km}$ with the grid spacing is 0.25 $\mathrm{km}$.

\section{Comparison of the Two Methodologies}

To compare these two odour assessment method, the odour level evaluation was performed by compare graphically the trend of the odour concentration at morning, evening and night time for those three days inspection. Then the comparison of the odour concentration values was examined in the field inspection versus the values estimated by CALPUFF. Besides that, this research will also computed the CALPUFF model performance and field inspection, which one is suitable to be use in Malaysia, how well CALPUFF produce the results and the relationship between the odour at the receptors with these two methods. Both method was relies on the human odour threshold acceptable level between $2 \mathrm{OU} / \mathrm{m}^{3}$ to $5 \mathrm{OU} / \mathrm{m}^{3}[8]$.

\section{Results and Discussion}

\section{Field Inspection Odour Concentration at the Receptors}

Field inspection was run around $4 \mathrm{~km}$ radius from the mill at the possible affected receptors. The odour frequency from the assessment by using in-field olfactometry can be seen in Fig. 3 and Fig. 4. Each receptor recorded nine odour observations and from the results, not all the odour data was came from the mill. Only $13 \%$ of the data that really came from the mill and the others were came from background odour such as grass, smoke from open burning or from the factory stack, exhaust from vehicle and also drainage. The highest odour frequency from the mill can be detected at receptors EXT1 and EXT3 with $44 \%$ and with the maximum distance less than $1.5 \mathrm{~km}$ from the source. The field inspection indicated zero odour frequencies in some locations such as at EXT9 and EXT10. This situation happen because of the time during the inspection did not match the time when the odours pass through the observation point. Odour spread with the wind and wind is one of the factors that affect the gas concentration and its dispersion. The gases that disperse will expend in volume and it will incorporate dilution air from around it, thus, the gas concentration will reduce due to its dispersion. These phenomena will reduce the concentration of the gases once it is arrives at the receptor. Besides that, the gases puffs are experience random movements due to the turbulence and will deflect away from the mean direction. When it happen, even though the receptor is just near the source, but if the wind direction change, the receptor will not affected by the smell.

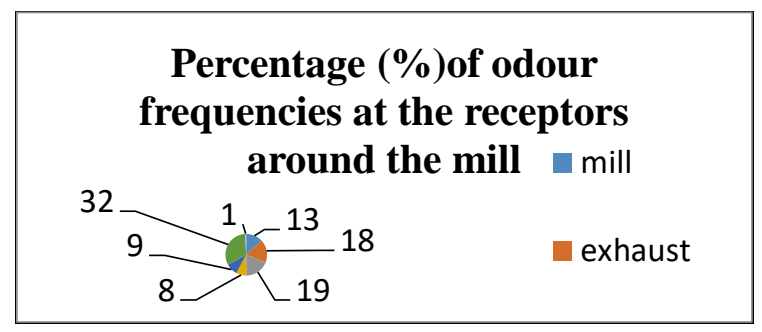

Fig. 3 Overallpercentage (\%) of odour frequencies at the receptors in three alternate days during morning, evening and night observation.

\section{Frequencies of the odour from mill by receptors}

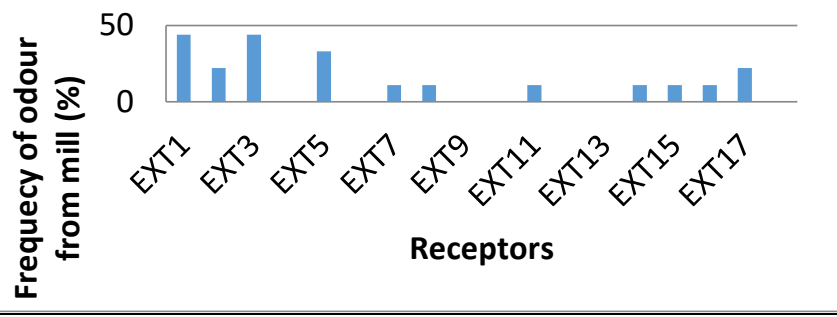

Fig. 4 Odour frequencies from the POME at the 18 possible receptors around the mill

\section{CALPUFF Atmospheric Odour Prediction}

Fig. 5 shows the results of the odour dispersion for day one and three at each monitoring time. The model calculates hourly mean odour concentration. Most of the odour concentrations during day time were starts from scale $10 \mathrm{OU} / \mathrm{m}^{3}$ to $1 \mathrm{E}-7 \mathrm{OU} / \mathrm{m}^{3}$ and from the prediction, only night time the contour start with $10 \mathrm{OU} / \mathrm{m}^{3}$. One important consideration concerns are the shape of the odour dispersion during three monitoring time which turned out to have different orientations with same MM5 data used. This is due mainly to wind factors and some of it from geographical data. Same MM5 data does not mean same wind speed and direction being applied but all of it is depends on the date and time.Another interesting consideration derives from the comparison of the dispersion modeling results at each monitoring time is the results of the olfactometric analyses. A small different of the results from the olfactometry analyses can change drastically the odour emission at the impact area, but, it also still depends on the wind direction and its speed.

The influence of wind speed and its direction can obviously be seen in Fig 5. There are huge different during day and night time prediction. During morning and evening session, the movements of the odour particles are stretched mostly to North-East direction when most of the wind blowing on that direction at that time. Besides that, results also shows that the odorous plume was less smooth in the evening compare to morning session. This situation happens because of the wind stability factor and its speed. From the contours, the wind during morning session is more stable than evening which makes morning contour are smooth compare to the evening contour. The clear different can be seen during day and night prediction.

From the contour, it is clearly shows that the higher odour emission can be detected almost $5 \mathrm{~km}$ radius in all direction, compare during day time where $5 \mathrm{~km}$ distance at only North-East direction. Wind speed and wind direction are the parameters that affected the gas concentration and its dispersion [17]. The gases that disperse far from the source will expend in volume and it will incorporate dilution air from around it, thus, the gas concentration will reduce due to its dispersion [18]. These phenomena will reduce the concentration of the gases once it is arrives at the receptor. But when the odour did not disperse, it will not go through the dilution process resulting in high odour concentrations at the ground level [18].

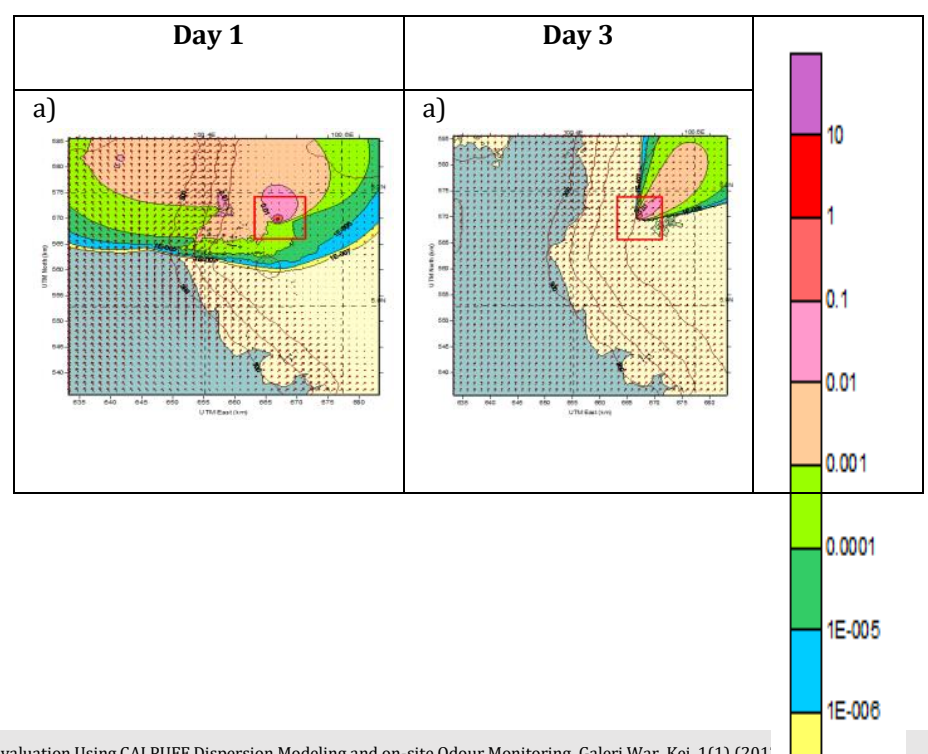




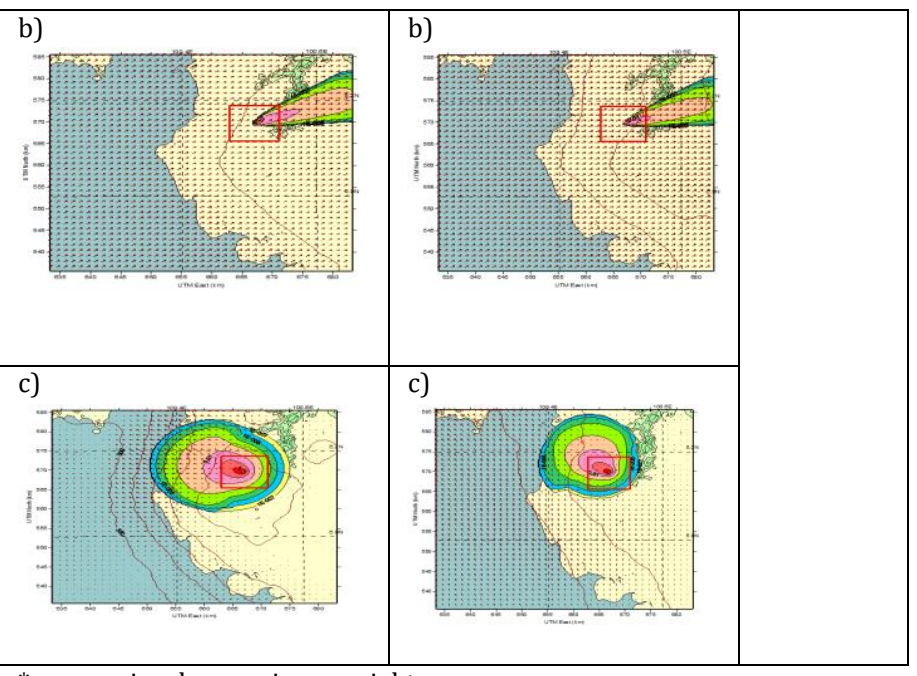

*a= morning, b= evening, $\mathrm{c}=$ night

Fig. 5 Day 1 and 3 of the odour dispersion during morning, evening and night time by using CALPUFF

\section{Comparison between Field Inspection and CALPUFF Prediction}

In this work, two techniques for estimating the odour nuisance was compared in terms of frequency of odor hours, caused by POME wastewater treatment plant. Those methods are field inspection, which is the analysis of reports from on-site human assessors, and the atmospheric dispersion model, CALPUFF. Their estimates of odor nuisance were generally similar but displayed some key differences. Indeed the scope of this paper was not to highlight a perfect match between the techniques, but rather to discuss differences, strengths and weaknesses emerging from the comparison. From the qualitative point of view, the two techniques were in good agreement but not in quantitative point where it is hard to get the same values from both of the methods. Differences in shape could be described the limits of the field inspection methodology, since sampling in the field involved a limited number of points for discontinuous periods of time. Instead, the model simulated odors during all time steps in all the points of the spatial domain, thus it should bring out more clearly the pattern and characteristics of the plume such as its stretched and relatively-irregular shape.

For both methodologies, the core of the nuisance was centered around the odorous sources, but with different intensity peak values. The field inspection indicated zero odour frequencies in some locations, unlike CALPUFF, and estimated a high frequency of odour episodes for other points. CALPUFF estimated a high frequency of odour episodes for other points as CALPUFF can give the whole picture of odour concentration compare to the field observation.

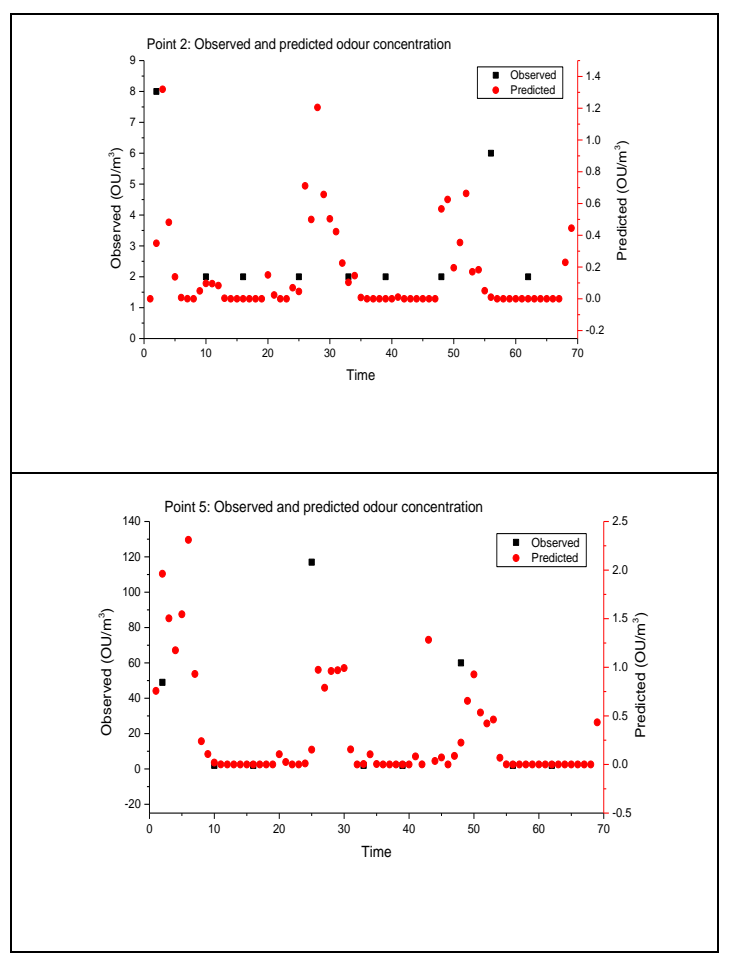

Fig. 6 The predicted and observed odour concentration values by time for point EXT2 and EXT5

The odour concentration values assessed by CALPUFF and field inspection in the single measurement points were showing no similarity in odour concentration values but same in the trend of the increasing and decreasing of the concentration values. From the qualitative point of view, Fig 6 shows that the trend of both predicted and observed odour concentrations mostly are the same. Both techniques were in good agreement based on the shape of the graph, where when the odour concentration for observed is increase, the prediction value is also increase.

But there are also some values that did not match. On day 2 at time 56 the observed value was over predicted. Different in pattern may be the results of the limitation of field inspection since samples from the study area were analyse by human assessor as human judgment are sometimes different and not consistent. Besides that, the field inspection is limited in number of assessment for continuous period of time where the exact pattern of the odour emission cannot be determined. As Ranzato et al. said, the model simulated odours during all period of time of the domain area which make the simulation of the odour can be seen more clearly [6].

Atmospheric dispersion is much more advance and being suggested nowadays because it can read the odour level even at the lowest odour episode compare with the field inspection where when odour levels are lower and odor episodes are rarer it cannot easily distinguished by human assessors.

CALPUFF provided lower nuisance estimates than field inspection in the points where odour frequencies estimated by the field inspection were highest, this is because, in general, the model does not underestimate high frequencies, but has a reduced accuracy close to emission sources [6]. Moreover, in general it would expected that field inspection to overestimate odours rather than underestimating them, because an assessor can fail to recognize an odor episode, while it seems less likely that an assessor smells an odor which is not present.

However, to get a good view and results from CALPUFF, it requires a great number of inputs such as detailed meteorological and geophysical data to avoid uncertainty in the simulations. Besides that, it also needs realistic emission rates value, which are sometimes difficult to estimate due to the complexity of odour substances and of emission sources such as the changing of the odour concentration with temperature. On the other hand, field measurements recorded on site should be well representative of the existing conditions. However, for the prediction, field inspection is not recommended to be used since it will be more expensive than the implementation of a model. This is because, it will need a greater number of people involved, with sufficient number of equipments and the long monitoring time required. Besides that, its performance can be influenced by sampling discontinuity in time and space, human error and subjectivity, and the simultaneous presence of more odours in the same place.

\section{Conclusion}

From the results, it is suggesting that there is room to improve the precision of the two methods and both of it can be use together to achieve a strong results and strengthen the odour assessment in Malaysia. Despite the differences between CALPUFF and field inspection estimates, their general agreement suggests that both methods provide reasonable estimates of the real odour nuisance, so that their applied use is justified. This work also shows how it is possible to assess odour impact in presence of multiple similar sources by illustrating a case study. Even though field inspection method cannot be used in the prediction purpose, it still can allowed to be use to identify the receptors or area that affected by the odour source in real situation. By using the model application, the field inspection result can be proved right in the means of the presence of the odour.

\section{Acknowledgement}

This work is supported by Universiti Sains Malaysia under the RUI grant no. 1001 / PAWAM / 814236. The authors also like to acknowledge United Oil Palm (UOP) Mill for their assistance during the sampling period. 


\section{References}

[1] N. S. Azmi and K. F. M. Yunos, "Wastewater Treatment of Palm Oil Mill Effluent (POME) by Ultrafiltration Membrane Separation Technique Coupled with Adsorption Treatment as Pre-treatment," Agric. Agric. Sci. Procedia, vol. 2, pp. 257-264, 2014.

[2] S. Sironi, L. Capelli, P. Céntola, R. Del Rosso, and M. I. Grande, "Odour emission factors for assessment and prediction of Italian rendering plants odour impact," Chem. Eng. J., vol. 131, no. 1-3, pp. 225-231, 2007.

[3] P. Henshaw, J. Nicell, and A. Sikdar, "Parameters for the assessment of odour impacts on communities," Atmos. Environ. vol. 40, no. 6, pp. 1016-1029, 2006.

[4] L. Capelli, S. Sironi, R. Del Rosso, P. Céntola, and M. Il Grande, "A comparative and critical evaluation of odour assessment methods on a landfill site," Atmos. Environ., vol. 42, no. 30, pp. 7050-7058, 2008.

[5] J. A. Nicell, "Assessment and regulation of odour impacts," Atmos. Environ., vol. 43, no. 1, pp. 196-206, 2009.

[6] L. Ranzato, A. Barausse, A. Mantovani, A. Pittarello, M. Benzo, and L. Palmeri, "A comparison of methods for the assessment of odor impacts on air quality: Field inspection (VDI 3940) and the air dispersion model CALPUFF," Atmos. Environ., vol. 61, pp. 570-579, 2012.

[7] G. Schauberger, M. Piringer, and E. Petz, "Separation distance to avoid odour nuisance due to livestock calculated by the Austrian odour dispersion model (AODM)," Agric. Ecosyst. Environ., vol. 87, no. 1, pp. 13-28, 2001.

[8] E. Sommer-Quabach, M. Piringer, E. Petz, and G. Schauberger, "Comparability of separation distances between odour sources and residential areas determined by various national odour impact criteria," Atmos. Environ., vol. 95, pp. 20-28, 2014.

[9] R. Muñoz, E. C. Sivret, G. Parcsi, R. Lebrero, X. Wang, I. H. M. Suffet, and R. M. Stuetz, "Monitoring techniques for odour abatement assessment.," Water Res., vol. 44, no. 18, pp. 512949, 2010.

[10] L. Capelli, S. Sironi, P. Céntola, R. Del Rosso, and M. Il Grande,
"Electronic noses for the continuous monitoring of odours from a wastewater treatment plant at specific receptors: Focus on training methods," Sensors Actuators B Chem., vol. 131, no. 1, pp. 53-62, 2008.

[11] J. Nicolas, J. Delva, P. Cobut, and A. C. Romain, “Development and validating procedure of a formula to calculate a minimum separation distance from piggeries and poultry facilities to sensitive receptors," Atmos. Environ., vol. 42, no. 30, pp. 70877095, 2008.

[12] J. I. Levy, J. D. Spengler, D. Hlinka, D. Sullivan, and D. Moon, "Using CALPUFF to evaluate the impacts of power plant emissions in Illinois: Model sensitivity and implications," Atmos. Environ., vol. 36, no. 6, pp. 1063-1075, 2002.

[13] L. Wang, D. Parker, C. Parnell, R. Lacey, And B. Shaw, "Comparison of CALPUFF and ISCST3 models for predicting downwind odor and source emission rates," Atmos. Environ. vol. 40, no. 25, pp. 4663-4669, 2006.

[14] J. Ariunbaatar, E. Scotto, D. Perta, A. Panico, L. Frunzo, G. Esposito, P. N. L. Lens, and F. Pirozzi, "Effect of ammoniacal nitrogen on one-stage and two-stage anaerobic digestion of food waste," Waste Manag., vol. 38, pp. 388-398, 2015.

[15] N. Hudson, G. a. Ayoko, M. Dunlop, D. Duperouzel, D. Burrell, K. Bell, E. Gallagher, P. Nicholas, and N. Heinrich, "Comparison of odour emission rates measured from various sources using two sampling devices," Bioresour. Technol., vol. 100, no. 1, pp. 118$124,2009$.

[16] S.-J. Jeong, "CALPUFF and AERMOD Dispersion Models for Estimating Odor Emissions from Industrial Complex Area Sources," Asian J. Atmos. Environ., vol. 5, no. 1, pp. 1-7, 2011.

[17] M. Lateb, C. Masson, T. Stathopoulos, and C. Bédard, "Effect of stack height and exhaust velocity on pollutant dispersion in the wake of a building," Atmos. Environ., vol. 45, no. 29, pp. 51505163, 2011.

[18] H. Guo, Y. Li, Q. Zhang, and X. Zhou, “Comparison of four setback models with field odour plume measurement by trained odour sniffers," vol. 48, pp. 39-48, 2006. 